\title{
Technology Adoption and Consumer Payments: Evidence from Survey Data
}

\author{
FUMIKO HAYASHI*
}

Payments System Research, Federal Reserve Bank of Kansas City

ELIZABETH KLEE

Division of Reserve Bank Operations and Payment Systems, Board of Governors of the Federal Reserve System

\begin{abstract}
Consumers pay for hundreds of goods and services each year, but across households and across goods, consumers do not choose to pay the same way. This paper posits that payment choices depend in part on consumers' propensity to adopt new technologies and in part on the nature of the transaction. To test this hypothesis, this paper analyzes consumer's payment instrument use at the point of sale and for bill payment. The sample includes consumers surveyed in 2001, who are primarily users of the Internet. The results indicate that consumers who use new technology or computers are more likely to use electronic forms of payment, such as debit cards and electronic bill payments. Particularly, the use of direct deposit is a significant predictor of electronic payment use. Furthermore, the results indicate that payment choice depends on the characteristics of the transaction, such as the transaction value, the physical characteristics of the point of sale, and a bill's frequency and value variability.
\end{abstract}

\section{Introduction}

Consumers pay for goods and services every day, and consumers do not always choose to pay the same way. At the point of sale, U.S. consumers generally have a choice of four payment instruments: cash, check, credit card, and debit card. To pay bills, many U.S. consumers use checks, but some have started to use other payment instruments, such as direct bill payment, online bill payment, and credit cards. ${ }^{1}$ In 2000 , checks represented the largest share of the volume of retail noncash payments (59.5 percent), followed by credit cards (28.9 percent), debit cards (11.6 percent), and retail ACH payments (5.6 percent). Recent estimates of the purpose of consumer check transactions indicate that 29 percent of consumer check payments are at the point of sale, 36 percent are for bill payments, and 13

* Contact author. Mailing address: 925 Grand, Kansas City, MO 64198. E-mail: fumiko.hayashi@kc.frb.org This paper reflects the views of the authors and not necessarily those of Federal Reserve Bank of Kansas City or the Board of Governors of the Federal Reserve System. We thank Jeff Marquardt, Jack Walton, Stu Weiner, and Rick Sullivan for helpful comments and suggestions. We also thank Laurance Blose and participants at the Midwest Finance Association 2003 Annual meetings for comments.

${ }^{1}$ A direct bill payment uses the automated clearinghouse $(\mathrm{ACH})$, which directly transfers funds between bank accounts. 
percent may be either point of sale or bill payments. ${ }^{2}$ These statistics show that more than one payment instrument is used in equilibrium, and the same payment instrument may be used for more than one purpose.

This paper focuses on the demand factors of payment choice. We ask two questions in this paper. First, does a consumer's use of new technologies contribute to predicting the probability that the consumer will use electronic forms of payment? We find that consumers who use new technologies are more likely to use electronic forms of payment. In particular, direct deposit use is a significant predictor of electronic payment use, specifically, the use of debit cards and electronic bill payments. Second, do the characteristics of the transaction, based on the type of establishment where the transaction occurs, affect the choice of payment instrument? The results indicate that payment choice depends on the characteristics of the transaction.

The analysis is performed on a new sample of U.S. consumers surveyed in 2001, drawn primarily from users of the Internet. The sample we analyze differs from the general U.S. population in one important respect: most of the respondents use computers and the Internet. About 60 percent of the survey participants responded via the Internet. We use this sample construction to test the first hypothesis. The survey is also unique in providing the information on consumer payment choices at different types of point of sale and for different types of bills. This information allows us to test the second hypothesis.

This paper contributes to the existing literature on payment systems by using new data to investigate factors that influence consumer adoption of electronic payments. Previous studies on consumer payment choice mainly focus on consumer's demographic and financial characteristics. ${ }^{3}$ These studies, which cover a large part of the period when electronic payments became more widespread, consistently indicate that consumers who are younger and wealthier more often adopt electronic forms of payment. Besides consumer demographic and financial characteristics, this paper focuses on consumer technology adoption and transaction characteristics. Previous research on technology adoption in other sectors indicates that the propensity to adopt one new technology may be correlated with the propensity to adopt another new technology. ${ }^{4}$ This paper confirms this result in the context of electronic payments adoption. Few studies examined the effects of transaction characteristics on payment choice, not because those are not important but because data sets containing such information are rare. ${ }^{5}$ Understanding the factors that contribute to consumer's adoption of electronic forms of payment and the factors that contribute to payment choice overall is important. As electronics become more prevalent in the payment system, policymakers and banking professionals can use this information to make informed decisions and to promote efficiency in the payment system going forward. ${ }^{6}$

Equilibrium payment use, however, depends not only on what consumers choose to use, but also on what merchants and billers accept, and on what the banking system offers

\footnotetext{
${ }^{2}$ Gerdes and Walton (2002).

${ }^{3}$ Avery et al. (1986), Kennickell and Kwast (1997), Carow and Staten (1999), and Stavins (2001). Mantel (2000) includes consumer's new product adoption in his analysis.

${ }^{4}$ Huffman and Mercier (1991) study the determinants of farmers' adoption of two types of computer systems. They find that characteristics predicting the adoption of one technology also predict the adoption of another technology.

${ }^{5}$ Whitesell (1992) and Shy and Tarkka (2002) developed theoretical models that examine consumer's payment choice based on the total expenditure.

${ }^{6}$ Federal Reserve System (2002).
} 
to consumers and merchants/billers. ${ }^{7}$ A simple example is a credit card. A consumer cannot choose to use a credit card if no card issuer offers one. Even if a consumer has a credit card, if the merchant does not accept the credit card, the consumer cannot pay by that credit card. Our results may implicitly indicate the importance of these supply-related factors. After controlling for the demographic and new product adoption characteristics, the coefficients for some of the regional variables are significant. ${ }^{8}$ In the regions where the coefficients significantly increase the likelihood of using electronic payments, relatively more banks may supply those payments. At the same time, relatively more merchants or billers may accept those payments.

The paper proceeds as follows. Section 2 describes the data and analytical methodology. Section 3 presents summary statistics. Section 4 reports the model estimates and discusses the implications of these estimates. Section 5 presents conclusions and avenues for further research.

\section{Data description and analytical methodology}

The analysis focuses on consumer technology adoption and transaction characteristics to explain consumer payment choice. The paper tests two hypotheses. The first hypothesis is that consumer technology adoption can explain the consumer use of electronic payments. The second is that transaction characteristics affect consumer payment choice.

The primary analysis is performed on a sample of U.S. consumers surveyed in 2001 on behalf of the American Bankers Association (ABA). The ABA contracted with Dove Consulting, Inc. to conduct a survey of U.S. households on payment instrument use. The company distributed a total of 15,637 surveys nationwide $-5,744$ by mail and 9,893 by email, and received 1,499 completed surveys. 646 respondents submitted a paper survey and 853 submitted one via the Web. We eliminate 163 point of sale and 172 bill payment observations due to incomplete consumer characteristics and payment information, and we drop observations where the respondent is under 19 years old or resides in Canada. ${ }^{9}$ This leaves 1,283 and 1,275 usable responses for point of sale and for bill payments, respectively. ${ }^{10,11}$

The data is well suited for testing our two hypotheses. First, survey participants answered technology use questions. Besides consumer demographic and financial information, the data contains information on consumer use and adoption of six new technology products. We use four for the analysis: direct deposit, purchase over the Internet, computers, and cell phones.

\footnotetext{
${ }^{7}$ The market of payment instrument is known as a two-sided market: not only consumers but also merchants are customers of a payment instrument. See for example, Evans (2002) and Hayashi et al. (2003).

${ }^{8}$ Another explanation for the significance of location would be the existence of network externalities. McAndrews (1997) and Gowrisankaran and Stavins (2003) address this issue.

${ }^{9}$ We tested to see whether possible misclassification due to missing values biases our results, by using the method suggested by Hausman et al. (1998). The results indicate that the bias due to misclassification is not significantly different from zero.

${ }^{10}$ We call the sample for point of sale payments the Dove POS sample, and the sample for bill payments the Dove bill payment sample.

${ }^{11}$ Detailed sample information, such as response rate, missing and inconsistent replies, is available from the authors upon request.
} 
Second, survey participants answered point of sale and bill payment questions. The data contains information on consumer use of payment instruments at seven different types of points of sale and for eight different types of bills. This information is used to test the second hypothesis. We hypothesize that transaction characteristics affect the choice of payment instrument. Although the data does not contain information on each transaction's individual characteristics, it does contain information on establishment and bill types. We can, therefore, test whether average transaction characteristics at the point of sale or for the bill influence consumer payment choice.

Two separate estimation procedures are used to test the two hypotheses. To test the first hypothesis, we use a series of logit regressions. Three different specifications are used for each payment instrument, to examine the importance of consumer technology adoption in predicting the likelihood of using each of the electronic payment instruments. For the second hypothesis, we test whether point of sale or bill characteristics affect payment choice. For each payment method, a binomial logit model that includes characteristics of points of sale or of bills as independent variables is estimated. The estimation procedure maximizes the conditional likelihood function, which allows us to eliminate consumer characteristics as a fixed effect and to estimate the effects of point of sale characteristics or bill characteristics. ${ }^{12}$ This procedure, however, has a downside. Since observations that use a particular payment method at zero or all establishments (bills) contribute nothing to the conditional likelihood function, coefficients on those characteristics may be overestimated.

\section{Summary statistics}

Table 1 presents summary statistics for our Dove samples, plus a comparison to the samples of two national surveys of consumers. The first comparison survey is the 1998 Survey of Consumer Finances (SCF). ${ }^{13}$ The SCF surveys a cross-section of U.S. households. It is conducted triennially by the Federal Reserve in conjunction with the National Opinion Research Center at the University of Chicago (NORC). The second comparison survey is the Current Population Survey (CPS) Computer and Internet Use Supplement of August 2000, which outlines computer use by different segments of the population. $^{14}$

Distinct differences between the Dove samples and the two national surveys can be seen in new product adoption. About 70 percent of the Dove respondents use the Internet to purchase goods, while the national average is only 19 percent. Both Dove samples also have a higher percentage of computer users (83 percent) than the CPS supplement (64 percent). Compared with the SCF sample, a smaller percentage of the Dove respondents use direct deposit. This difference, however, may be negligible, because a greater

\footnotetext{
${ }^{12}$ The estimation procedure follows Chamberlain (1984).

13 The SCF employs a dual-frame sample design. One is a standard, geographically based random sample and the other is a special oversample of relatively wealthy families. To eliminate the second sample, we eliminate households with more than $\$ 3$ million in stocks, bonds, and liquid assets; households with more than $\$ 375,000$ annual income; households with more than $\$ 10,000$ in credit card debt; and households with credit card debt that exceeds credit line limits. We also eliminate households with no annual income and households with less than a high school education, to be consistent with the Dove samples. For details on the structure of the SCF, see Kennickell $(1998,2000)$.

${ }^{14}$ We eliminate respondents under 19 years old or with zero income from the Supplement sample. For details on the structure of the CPS and its supplements, see U.S. Department of Labor (2000).
} 
percentage of the SCF sample are people aged 65 or over, who likely receive social security benefits via direct deposit.

\begin{tabular}{|c|c|c|c|c|c|}
\hline \multirow[t]{3}{*}{ Variable } & \multirow[t]{3}{*}{ Scale } & \multicolumn{4}{|c|}{ Summary statistics } \\
\hline & & \multicolumn{2}{|c|}{ Dove } & \multirow{2}{*}{$\mathrm{SCF}$} & \multirow{2}{*}{$\begin{array}{l}\text { CPS } \\
\text { Supplement }\end{array}$} \\
\hline & & Point of Sale & Bill payment & & \\
\hline \multicolumn{6}{|l|}{ New product adoption } \\
\hline Direct deposit & $0:$ no, $1:$ yes & $.6469^{*}$ & $.6455^{*}$ & .6778 & \\
\hline Purchase over Internet & $0:$ no, $1:$ yes & $.7030^{* *}$ & $.7075^{* *}$ & & .1891 \\
\hline Computer & $0:$ no, $1:$ yes & $.8270^{* * *}$ & $.8353^{* *}$ & & .6403 \\
\hline Cell phone & $0:$ no, $1:$ yes & .6157 & .6094 & & \\
\hline \multicolumn{6}{|l|}{ Financial } \\
\hline \multicolumn{6}{|l|}{ Household income $^{\mathrm{a}}$} \\
\hline$\$ 20,000-\$ 39,999$ & $0:$ no, $1:$ yes & $.2603^{*, * *}$ & $.2635^{*, * *}$ & .2893 & $.2361^{\mathrm{d}}$ \\
\hline$\$ 40,000-\$ 59,999$ & $0:$ no, $1:$ yes & $.2229^{* *}$ & $.2188^{* *}$ & .2006 & $.1953^{\mathrm{d}}$ \\
\hline$\$ 60,000-\$ 99,999$ & $0:$ no, $1:$ yes & .2245 & .2212 & .2069 & $.2367^{\mathrm{d}}$ \\
\hline Over $\$ 100,000$ & $0:$ no, 1 : yes & $.1707^{*}$ & $.1733^{*}$ & .1008 & $.1560^{\mathrm{d}}$ \\
\hline \multicolumn{6}{|l|}{ Demographic } \\
\hline \multirow[t]{2}{*}{ Education } & 0: high school, & $7536^{*}, * *$ & $7435^{*, * *}$ & & \\
\hline & $\begin{array}{l}\text { 1: college, } \\
\text { 2: graduate school }\end{array}$ & .7536 & .7435 & .8006 & .7221 \\
\hline Female & $0:$ no, $1:$ yes & $.5900^{*, * *}$ & $.5945^{* * * *}$ & .2682 & .5222 \\
\hline \multicolumn{6}{|l|}{$\operatorname{Age}^{b}$} \\
\hline 35-64 years old & $0:$ no, $1:$ yes & $.6890^{* * * *}$ & $.6957^{* * * *}$ & .5734 & .5530 \\
\hline Over 65 years old & $0:$ no, $1:$ yes & $.1122^{* * * *}$ & $.1067^{* * *}$ & .1964 & .1223 \\
\hline \multicolumn{6}{|l|}{ Census division ${ }^{c}$} \\
\hline New England & $0:$ no, $1:$ yes & $.0764^{* * *}$ & $.0769^{* * *}$ & .0524 & .0507 \\
\hline Mid-Atlantic & $0:$ no, $1:$ yes & .1372 & .1341 & .1496 & .1352 \\
\hline South Atlantic & $0:$ no, $1:$ yes & .1645 & .1671 & .1782 & .1832 \\
\hline ES Central & $0:$ no, $1:$ yes & .0561 & .0549 & .0624 & .0060 \\
\hline WS Central & $0:$ no, $1:$ yes & $.0779^{* *}$ & $.0784^{* *}$ & .0904 & .1008 \\
\hline WN Central & $0:$ no, $1:$ yes & .0787 & .0816 & .0732 & .0752 \\
\hline Mountain & $0:$ no, $1:$ yes & .0717 & .0745 & .0779 & .0673 \\
\hline Pacific & $0:$ no, $1:$ yes & .1574 & .1569 & .1398 & .1623 \\
\hline
\end{tabular}

\section{Table 1: Variable definitions and summary statistics}

Notes: All figures are in percent. Entries are means of each variable. "Indicates statistic is significantly different from SCF at the 95 percent confidence level. ${ }^{* *}$ Indicates statistic is significantly different from CPS Supplement at the 95 percent confidence level. ${ }^{\text {a }}$ The baseline for this variable is household income under $\$ 20,000$. ${ }^{\mathrm{b}}$ The baseline for this variable is 19-34 years old. ${ }^{\mathrm{c}}$ The baseline for this variable is EN Central. ${ }^{\mathrm{d}}$ The statistic reflects the CPS. The CPS Supplement is income-topcoded at $\$ 100,000$.

In contrast with statistics on new product adoption, statistics on demographics, financial, and regional characteristics of the Dove samples are somewhat similar to the SCF and the CPS supplement. Nevertheless, the Dove samples have a higher percentage of individuals in upper income ranges, a higher percentage of women, a higher percentage of middle-aged people (defined as 35-64 years old), and a higher percentage of people with 
more than a college education than the nationally representative data sets. ${ }^{15}$ The Dove sample regional distribution is relatively similar to the nationally representative data sets.

Table 2(a) presents summary statistics on point of sale payment. Respondents were asked which two payment methods they typically use at each type of establishment. We report the distribution of payment preferences for respondents who indicated preferences for all establishment types. ${ }^{16}$ Payment use may be correlated with the dollar amount of the sale: 59 percent of respondents use credit cards at department stores while 16 percent use them at fast food restaurants; and almost all use cash at fast food restaurants, but only 55 percent report using cash at department stores. However, the sale amount may not be the only determinant of payment choice. Approximately 72 percent of respondents report using cash at grocery stores, but only 63 percent report using cash at discount stores. The transaction values at these types of stores may be similar. Checks are less likely to be used at gas stations, restaurants, and fast food restaurants. Gas stations and restaurants are similar in the sense that the customers do not typically pay at the cashier.

Table 2(b) presents statistics for payment choice for different types of bills. Respondents were asked which two payment methods they typically use for each type of bill. We report the distribution of payment preferences for respondents who indicated preferences for all types of bills. ${ }^{17}$ Overall, the majority of respondents use checks to pay all types of bills. However, checks are not the only payment instrument used to pay the same type of bill. For example, 17 percent of respondents report using credit cards to pay tuition. Direct bill payments were used by the highest percentage of respondents to pay loans and insurance, and online bill payments were used most frequently to pay credit card bills.

\begin{tabular}{|l|c|c|c|c|}
\hline Point of Sale Type & Cash & Check & Credit Card & Debit Card \\
\hline Grocery Store & 71.64 & 45.80 & 26.68 & 44.64 \\
Gas Station & 76.26 & 17.86 & 51.16 & 36.55 \\
Department Store & 54.73 & 43.70 & 58.82 & 30.99 \\
Discount Store & 63.55 & 50.32 & 41.60 & 30.25 \\
Drug Store & 71.65 & 45.59 & 35.50 & 33.93 \\
Restaurant & 81.20 & 19.54 & 56.30 & 27.10 \\
Fast Food Restaurant & 97.58 & 16.18 & 15.97 & 13.76 \\
\hline
\end{tabular}

Table 2(a): Payment use by point of sale type

Notes: Entries represent percentage of the sample who use the payment at a given type of store. Sample size $=952$. Only respondents who indicated payment preferences for all stores are included in sample

\footnotetext{
${ }^{15}$ Gender comparisons may be misleading. The unit of observation in the Dove survey is a respondent, and the unit of observation in the SCF is a household. If a household in the SCF has both a male and a female, it is coded as a male headed household. For details, see Kennickell (2000).

${ }^{16}$ The sample size is, therefore, reduced to 952.

${ }^{17}$ The sample size is reduced to 652 .
} 


\begin{tabular}{|l|c|c|c|c|c|c|}
\hline Bill Type & Cash & Check & $\begin{array}{c}\text { Credit } \\
\text { Card }\end{array}$ & $\begin{array}{c}\text { Debit } \\
\text { Card }\end{array}$ & $\begin{array}{c}\text { Direct } \\
\text { Payment }\end{array}$ & $\begin{array}{c}\text { Online } \\
\text { Payment }\end{array}$ \\
\hline Rent & 26.84 & 86.50 & 4.60 & 3.53 & 19.33 & 5.52 \\
Loan & 20.55 & 83.59 & 6.90 & 5.06 & 23.93 & 6.13 \\
Credit Card Bill & 17.02 & 86.66 & 2.45 & 5.37 & 13.19 & 13.80 \\
Insurance & 20.40 & 83.90 & 8.44 & 4.60 & 21.78 & 7.06 \\
Membership & 15.64 & 86.35 & 26.23 & 9.05 & 7.36 & 5.98 \\
Tuition & 32.82 & 85.58 & 17.02 & 4.14 & 4.29 & 2.76 \\
Utility & 24.54 & 85.89 & 9.36 & 6.13 & 15.18 & 9.51 \\
Charitable Contribution & 43.87 & 87.58 & 11.81 & 3.22 & 3.37 & 1.99 \\
\hline
\end{tabular}

Table 2(b): Payment use by bill type

Notes: Entries represent percentage of the sample who use the payment at a given type of bill. Sample size = 652. Only respondents who indicated payment preferences for all bills are included in sample.

\section{$4 \quad$ Estimation and results}

This section summarizes our estimation results and discusses the implications of the results. We present our results for the effects of new product adoption and for the effects of point of sale characteristics or bill characteristics separately.

\subsection{New product adoption}

We investigate the new product adoption hypothesis by estimating binomial logits of debit card use at the point of sale, direct bill payment, and online bill payment. We estimate our models on three samples of data - the Dove point of sale (POS) sample, the Dove bill payment sample, and the SCF. ${ }^{18}$ The Dove POS sample is used for debit card use at the point of sale, the Dove bill payment sample is used for direct and online bill payment, and the SCF is used for debit card use and direct bill payment. We use the SCF in order to provide a point of comparison for the Dove results. As we noted earlier, the SCF sample represents the national population and the Dove sample differs from national averages on some important dimensions, such as higher computer and Internet adoption rates. Thus, the Dove results may be subject to sample selection bias. Comparing Dove estimates to SCF estimates aids interpretation of our results.

We estimate three model specifications. The first specification includes only demographic, financial, and regional variables in order to offer a point of comparison to previous studies and to our other specifications. The second includes use of direct deposit as an independent variable. Although direct deposit use is not generally decided by consumers but by their employers or governments, direct deposit use may affect some consumers' awareness of electronic banking products and thus may affect electronic

\footnotetext{
${ }^{18}$ Since our estimation uses a logit model, we use the first data imputation for the SCF. The summary statistics of the SCF sample used here are not necessarily equal to those shown in the previous section.
} 
payment adoption. In addition, this specification allows us to compare new product adoption effects for the Dove sample and for the SCF, because the SCF includes information on direct deposit. The third specification includes three additional new product adoption variables - purchases over the Internet, computer use, and cell phone use - as independent variables. Adding these variables will help us to determine which variables significantly predict payment choice. For all of our specifications, the baseline income category is less than $\$ 20,000$, the baseline age category is 19-34 years old, and the baseline census division is Midwest: East North Central.

Table 3 presents our first set of estimation results. From the first specification, we see that consumer demographic and financial characteristics significantly affect payment choice. Income and age are significant predictors of payment choice for both samples; the one exception is the SCF direct bill payment results. While the coefficient on education for the SCF sample is positive and statistically significant, the coefficient for the Dove sample is positive but is not statistically significant. This could result from the difference in computer usage between the Dove and the SCF samples. Education may act as a proxy for computer use in the SCF sample, but not in the Dove sample. Some regional coefficients are significant for both the Dove and the SCF samples; specifically, people who live in the Pacific region are more likely to use debit cards at the point of sale. Other regional coefficients are significant for one sample but not for the other. Overall, the results from the two samples are relatively similar, and our results are similar to the results of previous studies. ${ }^{19}$

According to our specification 2 results, for both samples, people who use direct deposit are more likely to use electronic payment instruments. Interestingly, in the Dove sample, some of the coefficients for income that are significant in the first specification are insignificant when direct deposit is included as an independent variable, while all the coefficients that are significant in the first specification remain significant in the SCF. Sample selection potentially explains this difference. As addressed above, the Dove sample has a higher computer use rate than the national average, and the SCF is a nationally representative sample. Also, computer use is positively correlated with income and some demographic characteristics. The Dove sample results may imply that technology adoption - computer use and direct deposit use - better predicts the use of debit cards and electronic bill payments than income or demographics. In the SCF sample, income and demographic characteristics may proxy for computer use, and thus, the Dove results and SCF results may be consistent. Regardless, direct deposit use significantly predicts electronic payment use.

In order to provide some intuitive interpretation for our results, we construct the predicted probability of using different payment instruments according to whether the respondent uses direct deposit. We construct these probabilities for a middle-aged male college graduate with income between $\$ 40,000$ and $\$ 59,999$ who lives in the Mid-Atlantic. The use of direct deposit by this person represents a 12.4 percentage point increase in the predicted likelihood of using debit cards at the point of sale in the SCF sample, and a 14.9 percentage point increase in the Dove sample. This difference in the estimated probability is even larger for direct bill payment. Using direct deposit represents a 24.1 percentage point increase for the SCF, and a 20.9 percentage point increase for the Dove sample.

\footnotetext{
${ }^{19}$ Avery et al. (1986), Kennickell and Kwast (1997), Carow and Staten (1999), Mantel (2000), and Stavins (2001).
} 
The third specification includes the three additional new product adoption characteristics for the Dove sample. We see that some of the new product adoption characteristics have a significant effect and that the effect of consumer's demographic and financial characteristics is diminished. Specifically, the coefficient on direct deposit remains significant, and the coefficient on purchases on the Internet is significant and positive for paying with a debit card at the point of sale and for using online bill payment. At the same time, none of the income variable coefficients is significant for all three payment methods, and one of the age coefficients that is significant in the first two specifications becomes insignificant for online bill payment. The results from this specification provide additional support for our hypothesis: if an individual uses new technologies, especially technologies closely related to the payment, the individual is more likely to use electronic forms of payment. Moreover, the estimates for online bill payment indicate that new product adoption characteristics are more important than demographic or financial characteristics to predict consumer electronic payment choice.

Another interesting finding is the effect of geographical location. Some of the coefficients on regional variables are significant for point-of-sale debit card use and online bill payment, but none is significant for direct bill payment. Living in the Pacific region positively affects the likelihood of using a debit card, and living in New England positively influences the use of online bill payments. Banks in those areas may supply those payment instruments more than the banks in other areas, or more merchants or billers may accept the payment instruments in those areas. Furthermore, direct bill payment use is not affected by location. This may be because a bank's supply of direct bill payment capability to the customers is uncorrelated with the geographical location of the bank.

Our hypothesis on new product adoption and electronic forms of payment fails if the demographic and financial characteristics are significantly collinear with new product adoption characteristics. We test the Dove sample independent variables for collinearity and find that there is not significant collinearity. ${ }^{20}$ This further strengthens our hypothesis that one type of technology adoption contributes to another type of technology adoption.

Although our results do not provide evidence for causality, the correlation between technology adoption in one sector and technology adoption in another sector is interesting from a consumer behavior perspective. Our results also leave open the possibility that supply side factors play a significant role. For example, once a bank starts providing direct deposit to its customers, it may use the same infrastructure to provide other types of electronic payments. Overall, our results indicate that new technology use by consumers significantly predicts their electronic payment use.

\footnotetext{
${ }^{20}$ A test statistic of 20 or above implies that significant collinearity exists in the data. The test statistics are 13.5 and 18.0 for the first and third specifications, respectively. See Besley et al. (1980).
} 


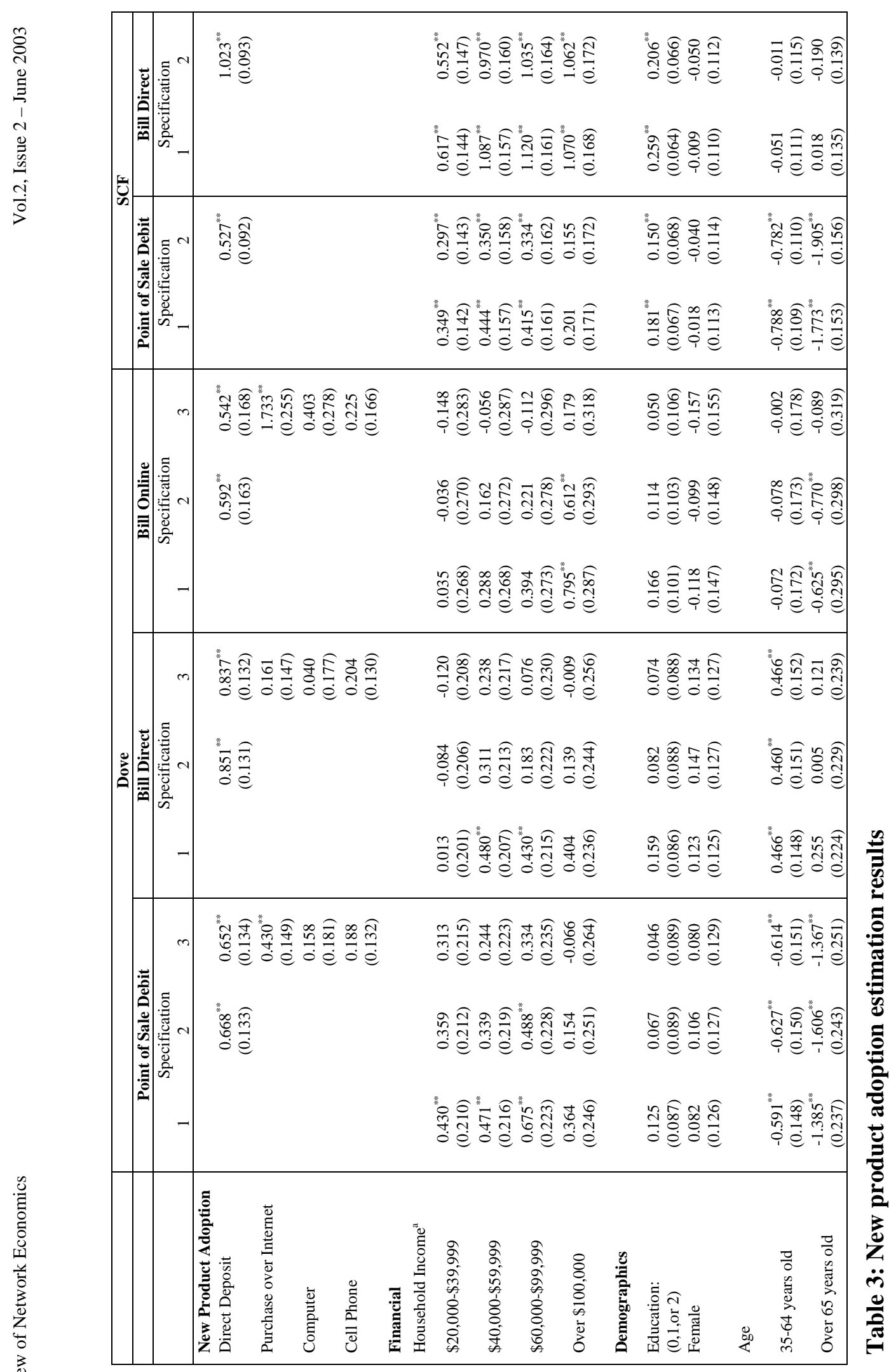




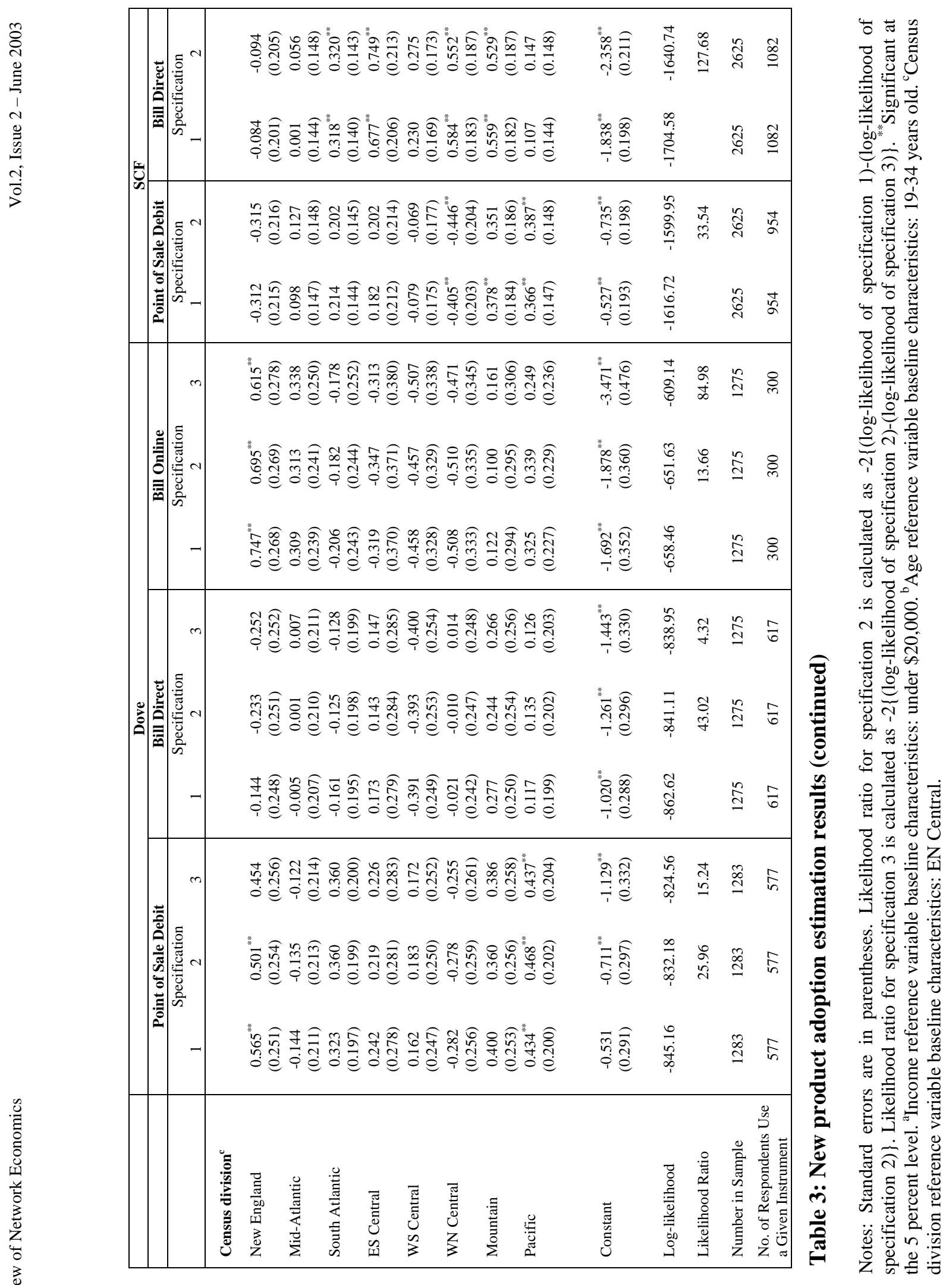




\subsection{Transaction characteristics}

Our second set of results examines the characteristics of point of sale and bill payments that determine payment choice. Here, we maximize the conditional likelihood function to eliminate the effects of consumer characteristics and to estimate the effects of establishment or bill characteristics. Our estimation procedure is as follows. Suppose, for example, that a consumer uses a debit card, at only one type of establishment, grocery stores. We formulate this consumer's probability of using a debit card at grocery stores conditional on the probability that he uses a debit card at any one of the establishments. The product of each consumer's conditional probability of using a particular payment instrument, such as above, forms the conditional likelihood function. The estimated parameters maximize the conditional likelihood function.

First, we report the point of sale payment results. There are seven types of establishments for POS transactions and three POS transaction characteristics: cashier presence, self-service, and value. The baseline categories for these characteristics are cashier present, no self-service, and mid-range value. Three POS establishments satisfy all of these criteria - grocery stores, discount stores, and drug stores. Hence, the estimated coefficients should be interpreted as relative to the transactions at these types of stores. Table 4(a) presents the coefficients and how differences in characteristics affect the "average" person's probability of using a particular payment. The predicted differences in probability give an intuitive sense of how the point of sale characteristics significantly determine payment choice. We define the average as the person whose predicted probability of using a particular payment method at the base establishment type (grocery stores, discount stores, and drug stores) equals the sample ratio of using this payment method at the base stores, conditional on using the payment method for at least one type of establishment. The statistic below the dotted line in each cell shows the difference between the probability of using the payment at the stores with and without the particular characteristic.

We find that point of sale physical characteristics, such as the absence of cashier or the availability of self-service, significantly affect payment choice. For point of sale payments, consumers tend to use cash more often if there is no cashier, or if there is self-service available. Cashier absence negatively affects the probability of check or debit card use, but positively affects the probability of credit card use. The availability of self-service has a positive effect on the probability of using a credit or a debit card, but a negative effect on the probability of paying with checks.

The average transaction value at the point of sale also significantly affects payment choice. Strikingly, the only positive coefficient for high-average transaction value is for credit card transactions. The predicted probability of using a credit card at establishments with high-average transaction value is 41 percentage points higher than that at establishments with mid-average transaction value. In contrast, the predicted probability of using cash, checks, and debit cards, at establishments with high-average transaction value is lower than that at establishments with mid-average transaction value by 31,7 , and 16 percentage points, respectively. Moreover, the predicted probability of using cash is relatively higher at establishments with low-average transaction value and the predicted probability of using check, credit cards, and debit cards at these establishment is relatively lower. 
Turning to the bill payment results, there are eight types of bills and there are two general categories of bill characteristics: frequency and value variability. The coefficients should be interpreted as relative to a transaction that is infrequent and is of variable dollar value, such as charitable contributions. Table 4(b) reports the coefficients on the bill characteristics and how the difference of the characteristics affects the "average" person's probability of using a certain payment method.

\begin{tabular}{|l|c|c|c|c|}
\hline Independent Variable & Cash & Check & Credit Card & Debit Card \\
\hline No Cashier & $1.2046^{* *}$ & $-2.9699^{* *}$ & $2.0565^{* *}$ & $-1.2083^{* *}$ \\
& $-(0.1161)$ & $(0.1370)$ & $(0.1176)$ & $(0.1266$ \\
\hline Self Service & $0.1855^{* *}$ & -0.6149 & 0.3912 & $-0.2883^{*}$ \\
& $0.6843^{* *}$ & $-3.2136^{* *}$ & $1.5426^{* *}$ & $0.0377^{* *}$ \\
& $(0.1087)$ & $(0.1420)$ & $(0.1104)$ & $(0.1268)$ \\
\hline High-average Value & 0.1219 & -0.6402 & 0.3270 & 0.0078 \\
& $-1.2985^{* *}$ & $-0.3845^{* *}$ & $2.3318^{* *}$ & $-0.7023^{* *}$ \\
& $(0.1109)$ & $(0.1127)$ & $(0.1229)$ & $(0.1261)$ \\
\hline Low-average Value & -0.3108 & -0.0794 & 0.4167 & -0.1626 \\
& $4.8809^{* *}$ & $-3.4760^{* *}$ & $-1.8803^{* *}$ & $-2.9226^{* *}$ \\
& $(0.3644)$ & $(0.1479)$ & $(0.1241)$ & $(0.1428)$ \\
\hline Log-likelihood & 0.2956 & -0.6626 & -0.3634 & -0.5917 \\
\hline Sample Size & -1020.190 & -904.054 & -1101.636 & -865.317 \\
\hline
\end{tabular}

\section{Table 4(a): POS - transaction characteristics}

Notes: The sample size is the number of observations used in estimation. Base $=$ (Grocery store, drug store, discount store). Log-likelihood is conditional on using payment instrument at a certain number of establishments. Standard errors are in parentheses. Predicted differences in probabilities from the base are below the dotted line. ${ }^{* *}$ Significant at the 5 percent level.

\begin{tabular}{|l|c|c|c|c|}
\hline Independent Variable & Check & Debit Card & $\begin{array}{c}\text { Direct } \\
\text { Payment }\end{array}$ & $\begin{array}{c}\text { Online } \\
\text { Payment }\end{array}$ \\
\hline Frequent Bills & $-0.2676^{* * *}$ & -0.1891 & $2.2721^{* *}$ & $1.9963^{* *}$ \\
& $(0.1313)$ & $(0.1741)$ & $(0.1503)$ & $(0.2277)$ \\
& -0.0192 & -0.0306 & 0.3728 & 0.3740 \\
\hline Fixed-amount Bills & $-0.3322^{* *}$ & 0.1263 & $0.8248^{* *}$ & $-0.9920^{* *}$ \\
& $(0.1321)$ & $(0.1769)$ & $(0.1143)$ & $(0.1812)$ \\
\hline Log-likelihood & -0.0245 & 0.0223 & 0.0838 & -0.0691 \\
\hline Sample Size & -506.852 & -271.939 & -665.919 & -241.876 \\
\hline
\end{tabular}

Table 4(b): Bill - transaction characteristics

Notes: The sample size is the number of observations used in estimation. Base $=$ (Charitable contribution). Log-likelihood is conditional on using payment instrument for a certain number of transactions. Standard errors are in parentheses. Predicted differences in probabilities from the base are below the dotted line. ${ }^{* *}$ Significant at the 5 percent level.

We find that bill characteristics have a great influence on payment choice, especially on electronic bill payments, such as direct bill payments and online bill payments. While consumers are less likely to use a check if a bill is frequent or fixed, the difference in 
predicted probability of using checks between the base type of bills and frequent bills or fixed-amount bills is relatively small. In addition, consumers who use a debit card to pay bills seem not to change their behavior according to bill type: no coefficient is significant and the difference between predicted probabilities is small. In contrast, a consumer's likelihood of using direct or online bill payments is significantly influenced by the bill type. Consumers use these two bill payment methods more for frequent bills, which is reflected in the substantial change in the predicted probabilities from the base bill type approximately 37 percentage points. Direct bill payment and online bill payment use differs according to fixed or variable dollar amounts: consumers use a direct bill payment more for fixed dollar amount bills, and use an online bill payment more for variable dollar amount bills. Part of this difference could stem from authorization methods. Consumers do not authorize direct bill payments each time, but do authorize each online bill payment. Thus, consumers may be more willing to use direct bill payment for fixed than for variable bill amounts.

Overall, these results point to the fact that the nature of the transaction is an important factor in payment used by consumers. Although we cannot distinguish between supplyrelated and demand-related causes, we find that both transaction value and other transaction characteristics may greatly influence consumer payment choice.

\section{Conclusions and suggestions for further research}

Our paper shows two things. First, consumers who use new technology products tend to use electronic forms of payment more than those who do not. In particular, direct deposit use and making purchases on the Internet contribute to a consumer's likelihood of using electronic payment methods. Second, transaction characteristics may affect payment choice. The results indicate that both transaction value and physical characteristics of the point of sale can influence payment choice, and that the choice of direct bill payments and online bill payments is significantly influenced by the bill characteristics.

Adopting one type of technology does not necessarily lead to adopting another type of technology. However, our results do indicate that use of one technology is significantly correlated with use of another, independent technology. From a payments perspective, because technology adoption does significantly predict electronic payment use, as more households use the Internet, cell phones, and direct deposit, more households may adopt electronic forms of payment. Adopting electronic forms of payment likely contributes to efficiency in the payment system and the overall economy.

Our results also shed light on the importance of transaction characteristics on a consumer's payment choice. Understanding which characteristics of the transaction make more consumers willing to use electronic forms of payment is important for both policymakers and businesses.

The model presented in this study has some limitations. First, the framework used is a demand framework only, and takes the supply of payment instruments as given. To form a clearer picture of payment choice, both demand and supply need to be included. For example, banks that do not offer their customers the ability to make direct bill payments limit the available payment alternatives. Even if banks offer such a service to their customers, if billers do not accept direct bill payments, consumers cannot use them. The 
regional variation in our results underscores the importance of including supply factors in the analysis.

Second, the demand framework itself has some limitations. Demographic and financial characteristics may determine a consumer's access to bank accounts or credit cards and thus limit the choice set, rather than determine the demand. The inability to distinguish between limited availability and choice potentially restricts analytical methods.

Finally, we share a fault with most payment choice studies - we do not have information on the price of these different payment instruments to consumers. ${ }^{21}$ Few data sets contain both fee and price information in conjunction with demographic and income information. Evidence exists that consumers may be price sensitive. In a study of direct payment behavior, 23 percent of non-users claimed that they would switch to an electronic form of bill payment if offered a 5 percent discount on the bill. ${ }^{22}$ Further research using price data may lend greater insight into the determinants of payment choice.

\section{References}

Avery, R.B., G.E. Elliehausen, A.B. Kennickell and P.A. Spindt (1986) "The Use of Cash and Transaction Accounts by American Families," Federal Reserve Bulletin, 72: 87-108.

Belsley, D.A., E. Kuh and R.E. Welsh (1980) Regression Diagnostics. New York: John Wiley and Sons.

Carow, K.A. and M.E. Staten (1999) "Debit, Credit or Cash: Survey Evidence on Gasoline Purchases," Journal of Economics and Business, 51: 409-421.

Chamberlain, G. (1984) Panel Data. In Z. Grilliches \& M.D. Intriligator (eds), Handbook of Econometrics, vol. II: 1247-1318. Amsterdam: Elsevier Science Publishers BV.

Evans, D.S. (2002) "The Antitrust Economics of Two-Sided Markets," AEI-Brookings Joint Center for Regulatory Studies, Related Publication 02-13.

Federal Reserve Financial Services (1998) A Summary of Consumer and Business Attitudes on Direct Deposit and Direct Payment. Available for download at http://www.stls.frb.org/banking/ach.

Federal Reserve System (2002) "The Future of Retail Electronic Payments Systems: Industry Interviews and Analysis," Board of Governors of the Federal Reserve System Staff Study 175.

Gerdes, G.R. and J.K. Walton, II. (2002) "The Use of Checks and Other Noncash Payment Instruments in the United States," Federal Reserve Bulletin, 88: 360-374.

Gowrisankaran, G. and J. Stavins (2003) "Network Externalities and Technology Adoption: Lessons from Electronic Payments," RAND Journal of Economics, forthcoming.

\footnotetext{
${ }^{21}$ See Hancock and Humphrey (1997). An exception to this is Humphrey et al. (2001), who estimate aggregate price elasticities with respect to payment instruments using Norwegian data.

${ }^{22}$ See Federal Reserve Financial Services (1998).
} 
Hancock, D. and D.B. Humphrey (1997) "Payment Transactions, Instruments and Systems: A Survey," Journal of Banking and Finance, 21: 1573-1624.

Hausman, J.A., J. Abrevaya and F.M. Scott-Morton (1998) "Misclassification of the Dependent Variable in a Discrete-Response Setting," Journal of Econometrics, 87: 239269.

Hayashi, F., R. Sullivan and S.E. Weiner (2003) "A Guide to the ATM and Debit Card Industry," Payments System Research Department Working Paper 02-03, Federal Reserve Bank of Kansas City.

Huffman, W.E. and S. Mercier (1991) "Joint Adoption of Microcomputer Technologies: An Analysis of Farmer's Decisions," The Review of Economics and Statistics, 73: 541-546.

Humphrey, D.B., M. Kim and B. Vale (2001) "Realizing the Gains from Electronic Payments: Costs, Pricing and Payment Choice," Journal of Money, Credit, and Banking, 33: 216-234.

Kennickell, A.B. (2000) Codebook for 1998 Survey of Consumer Finances. Board of Governors of the Federal Reserve System.

Kennickell, A.B. (1998) "Multiple Imputation in the Survey of Consumer Finances," mimeo, prepared for the August 1998 Joint Statistical Meetings, Dallas.

Kennickell, A.B. and M.L. Kwast (1997) "Who Uses Electronic Banking? Results from the 1995 Survey of Consumer Finances," Proceedings from the $33^{\text {rd }}$ Annual Conference on Bank Structure and Competition, Federal Reserve Bank of Chicago, 56-75.

Mantel, B. (2000) "Why do Consumers Pay Bills Electronically? An Empirical Analysis," Federal Reserve Bank of Chicago Economic Perspectives, 32-47.

McAndrews, J. (1997) "Network Issues and Payment Systems," Federal Reserve Bank of Philadelphia Business Review, 15-25.

Shy, O. and J. Tarkka (2002) "The Market for Electronic Cash Cards," Journal of Money, Credit, \& Banking, 34: 299-314.

Stavins, J. (2001) "Effect of Consumer Characteristics on the Use of Payment Instruments," Federal Reserve Bank of Boston New England Economic Review, 3: 19-31.

U.S. Department of Labor, Bureau of Labor Statistics, and U.S. Department of Commerce. (2000) Current Population Survey: Design and Methodology. Technical Paper No. 63.

Whitesell, W.C. (1992) "Deposit Banks and the Market for Payment Media," Journal of Money, Credit and Banking, 24: 483-498. 